\title{
SPORT EVENT ATTRIBUTES INFLUENCING SPORT TOURISTS’ ATTENDANCE AT SEPAK TAKRAW EVENT
}

\author{
AZADEH ZAREI,* KIRSTEN HOLMES,† AND AMINUDDIN BIN YUSOF* \\ *Department of Sport Studies, Universiti Putra Malaysia, Selangor, Malaysia \\ †School of Marketing, Curtin University, Bentley, Australia
}

\begin{abstract}
The use of traditional sports events as modern sport tourism products has grown rapidly over recent decades. This article investigated differences in sport attributes that influence sport tourists' behavioral choices for attending a sepak takraw event using the human and nucleus component of Leiper's tourism attraction system. The study uses a sample of 316 sport tourists including domestic sport tourists $(n=224)$ and foreign sport tourists $(n=92)$ attending ISTAF Super Series. The findings reveal different factors were important to domestic sport tourists compared to foreign sport tourists. Domestic respondents reported that sport event attributes such as convenience and accessibility, game attractiveness, and sport facility were important in their decisions to attend a sepak takraw event while foreign sport tourists perceived cost to be a necessary sport attribute for their attendance. This article provides support for a sepak takraw as an event product that offers new sport marketing opportunities for particular target market segments within small-scale sport tourism.
\end{abstract}

Key words: Small-scale sport events; Traditional sport events; Sport tourists; Sport event attributes

Introduction

This article seeks to examine how sport event attributes affected sport tourists attending a sepak takraw event. Sports event tourism has gained substantial importance in tourism strategies over recent decades. It is the fastest growing sector, which is considered as a means for developing the economy of local communities as well as promoting and rejuvenating tourism (Hinch \& Higham, 2011).
Scholarly interest in small-scale sport tourism is a relatively new frontier that advocates against the negative outcomes associated with mega-sport events such as the Olympic Games and the Football World Cup (e.g., Gibson, Kaplanidou, \& Kang, 2012). Such mega-events have become associated with a range of negative impacts. These include social impacts such as drug abuse, increasing crime, prostitution and bad behavior, removing domestics, disruption in their lifestyles by security 
issues, congestion and displacement, and intercultural tension (Fredline, 2005; Hall, 1992). This is a particular concern for mega-events, which are hosted in developing nations. For example, Pillay and Bass (2008) stated that South Africa's hosting of the 2010 World cup met with substantial complaints from marginalized communities who benefited little from the event.

In contrast, Higham (1999) in discussion stated that small-scale sport events, which are defined in this article to include regular season tournaments, international sporting fixtures, domestic competitions, and people with disability (PWD) sports, have the potential to have more benefits to communities. He noted that these events do not require expensive bid documents and far less investment for new facilities and infrastructure for hosting a one-off event. They also tend to be a more manageable size for host cities, which eases crowd trouble, less infrastructural congestion, and less risk of displacement for residents. These events would attract active sport tourists or competitors, spectator sport tourists, and others in all competitions and sports events (professional and amateur) that should be understood more.

The term "sport tourist" refers to a person who specifically travels away from their usual environment for a stay of at least $24 \mathrm{hr}$ for the purposes of watching a sport event (Gammon \& Robinson, 2003). In this case, sport is the primary motive for travel while touristic elements are secondary attractions, which may reinforce a sport tourist's overall satisfaction with their trip. This article uses Leiper's (1990) tourist attraction system, which includes three components: a tourist or human component, a nucleus component, and a marker component. Accordingly, "a tourist attraction comes into existence when the three elements are connected" (p. 371). The human element of Leiper's model refers to tourists' behaviors. The nucleus component of the tourist attraction system emphasizes the features of a sport event or a place. The nucleus involves the features of the sport event influencing the sport tourists' decision to travel and experience them in the host destination. In a sport attraction context, the nucleus may consist of the attributes of sport events such as the game form, rules of competition, and physical prowess displayed by the competitors.
Sepak takraw event can be considered as a form of small-scale sport events. Sepak takraw has been held with its traditional forms since the time of Sultanates of Malacca, dating back to 15th century in Malaysia. Sepak takraw means "kick ball" as "sepak" comes from Malay word meaning kick and "takraw" as a Thai word used for a rattan ball (Megat \& Virdati, 2012). Sepak takraw, as one of the toughest sports in the world, it is described as a spectacular blend of volleyball, football, martial arts, and gymnastics, which require physical fitness in a variety of forms and movements (http:///www. sepaktakraw.org/). However, over the past few decades the Malaysia and Thailand national governing bodies have transformed the sport to gain worldwide popularity and interest (Megat \& Virdati, 2012). This was done when the national teams of Malaysia and Thailand showcased sepak takraw to other Asian and world countries during international sepak takraw events since 1965. In addition, the International Sepak Takraw Asian Federation (ISTAF) and Persatuan Sepaktakraw Malaysia (PSM) have played a major role in introducing this sport to other counties and establishing small-scale sport tourism in Malaysia. ISTAF was formed in 1988 with five member countries including Malaysia, Thailand, Singapore, Indonesia, and Myanmar. Currently, there are almost 25 member associations from Asian and Western countries. Among international tourist arrivals to Malaysia, the King's Cup Sepak Takraw World Championships, ISTAF World Cup, and ISTAF Super Series have drawn significant international, local viewers, and competitors. Given the significance, there is much potential for sport and tourism authorities in Malaysia to harness the preferences of sport tourists as the consumers of sport.

This is needed in order to understand the human element of the Leiper's model, which addresses sport tourists' behaviors and demographic characteristics. Understanding sport tourists' behaviors and motives based on geography segment categorizes sport tourists with similar needs and wants into groups (Blann \& Armstrong, 2007; A. Smith, 2012), and determines those services that are effectively required for planning and marketing events to meet their needs (Yusof, Shah, \& Geok, 2010).

Effective sport tourism management also requires an understanding of sport tourists' preferred sport 
event's attributes that affect sport tourists' attendance. This is known as the nucleus element in Leiper's (1990) tourist attraction system. Sepak takraw may have specific attributes, which could be the key to attracting sport tourists. The importance of sport attributes with different types of core products, product attributes, and game products that increase attendance has been established through sport marketing (e.g., Ferreira \& Armstrong, 2004). Similarly, demand market is discussed about a set of the game constructs that sport teams could provide for their future consumers (e.g., Zhang, Piatt, Ostroff, \& Wright, 2005). Previous studies have identified the importance of sport attributes and their differences related to attendance in different sport settings (Bernthal \& Graham, 2003) such as particular sports (e.g., basketball, hockey, and baseball) (Hansen \& Gauthier, 1989). Sports tourists have also been segmented by geographic origin (Dolinting, Yusof, \& Soon, 2013; Popa, Yusof, \& Soh, 2017; Yusof et al., 2010) and gender of sport participants (women and men sports) (Ferreira \& Armstrong, 2004). However, the traditional sport event of sepak takraw has rarely been studied and little is known about how domestic and foreign sport tourists view such a traditional sport event. Thus, the major objectives of this article are to: a) investigate the demographic profiles of domestic and foreign sport tourists who attended a sepak takraw event in Malaysia and b) to investigate the differences in the perceived attributes of the sepak takraw event among domestic and foreign sport tourists in Malaysia.

\section{Sepak Takraw as Traditional Sport Event}

Traditional sport is characterized by a particular role in representing the cultural identity; a sport identity opposed to modern sport; specific regional origins and particularities; historical tradition, cultural complexity, and ethical quality (United Nations Educational, Scientific and Cultural Organization [UNESCO], 2005). Traditional games have morphed into a sport, which is attributed to two distinct characteristics (Lavega, 2006). The first characteristic involves establishing a governing body such as a federation, association, or organization that enforces standardized rules and regulations to produce the event. Because the implementation of rules and regulations is universal, the practice of the sport involves following the rules and regulations such as traditions, customs, and routines for a consistent, mature, respected, and recognizable event. The second feature of this type of sport is recognized and being honored in time by people, sport fans, and official sport bodies.

Asia has experienced a revitalization of traditional forms of sports, games, dance, and recreation as a result of the Sport Projects and ASEAN Traditional Games, which were launched in 1979 in order to promote the integration of South Asians and regional identity (Renson, 1992). The sport of sepak takraw goes back to the 15th century in Malaysia, the 16th century in Thailand, and as far back as the 11th century in the rest of south-eastern Asian countries such as Brunei, the Philippines, Myanmar, Indonesia, and Laos (http://www.sepak takraw.org/). Sepak takraw literally means "kick ball" as "sepak" emerged from Malay word meaning kick and "takraw" from a Thai word used for a rattan ball.

The first schemes outlining the regulations and rules of sepak raga game were codified in Malaysia in 1960. Sepak raga event appeared as a medal sport at the South-East Peninsular Games (the forerunner of South-East Asian Games or SEA) in 1965. The name of sepak raga was modified to sepak takraw by agreement among the key playing countries of Malaysia, Singapore, Thailand, and Burma leading to the permanent acceptance of the sepak takraw game by the SEAP Games Committee in 1965. The national teams of Malaysia and Thailand showcased sepak takraw to other Asian countries at the 1970 Asian Games in Bangkok. The Malaysia Sepak Takraw association (PSM) organized several sepak takraw shows in Adelaide, Australia in 1977 as well as touring China, South Korea, and Hong Kong in 1980. Malaysia was also enthusiastic about experience of the 1980 Asian Sepak Takraw Championship.

The data on sport tourism in Malaysia show that the 27th King's Cup Sepak takraw World Championships held in Kuala Lumpur, Malaysia brought 600 competitors and team officials representing 26 different countries from five continents (http://www.sepaktakraw.org/). The 2011 ISTAF World Cup was in Kuala Lumpur, Malaysia where the event drew over 4,000 international and 
local viewers. The tournament included 36 men's and women's national teams from different areas such as the US, France, Germany, Switzerland, and Australia and it drew 13 million TV viewers in Thailand, over 5 million in each of Malaysia and China, and 3 million in Europe.

\section{Theoretical Framework: \\ Tourist Attraction System of Leiper}

\section{Human Element or Sport Tourists}

This article uses Leiper's (1990) tourist attraction system to analyze sport tourists' motivations. Attractions, including events, are central to any tourist visit (Getz, 2008). Leiper proposed that tourists visited attractions - the nuclei of the tourist visit-as a result of their motivations. Leiper's model proposed the connection of three principles including a tourist or a human element, a nucleus or the attraction, and a marker or information source component as the functional tourist attraction system. Leiper described the nucleus as "any feature or characteristic of a place that a traveller contemplates visiting or actually visits” (Leiper, 1990, p. 372).

Leiper's model has been widely cited and tested by subsequent researchers. Richards (2002) used survey data from 6,000 visitors to cultural attractions and found strong evidence to support Leiper's premise that tourists' motivations pushed them towards attractions. A study by Higham and Hinch (2003) interviewed sport and tourism administrators and found that the Rugby Super 12 function as a primary tourism attraction suggested by Leiper, for the increasing attendances of domestic and foreign tourists from long distances. Two studies by Yusof et al. (2010) and Yusof, Shah, and Geok (2012) demonstrated that how the three elements of Leiper motivate tourist behavior in relation to a variety of sport tourist profiles across the Champions Youth Cup (CYC) in Lake Kenyir.

This article focuses on the traveler/sport tourist and their motivations to visit the nucleus/sport event. The human element or a tourist as the first principle is generally the subset of travelers and is classified according to his/her behaviors. Leiper (1990) defined tourists who can take a trip if they have individuals' nonmental and mental attributes, needs, and abilities. These are mainly considered as motives and demographic characteristics. Sport tourists' classifications in sport tourism are also based on their behaviors (e.g., Gibson, 2013; Hinch \& Higham, 2011; Standeven \& Knop, 1998). Nogawa, Yamaguchi, and Hagi (1996) in their study of Japanese sport tourists categorized sport tourists into three groups: (1) event participants are individuals whose primary purpose in traveling is to take part in an organized sport event; (2) event spectators include people whose primary purpose is to watch an organized sport event; and (3) sport lovers, those who travel to take part in "self-organized" sports.

Robinson and Gammon (2004) provided the hard definition of sport tourism that sport is a primary aim of traveling. Accordingly, people travel to and/ or stay in places outside their usual environment and actively or passively participate in a competitive sport event as a primary activity. Nauright (1996) noted "that many cases, sporting events and people's reaction to them are the clearest public manifestations of culture and collective identities in a given society" (p. 248). The distinctive view of his study was positioning sport as a cultural reflection of one or more than one cultural dimension that was publicly displayed in South Africa or other destinations.

This concept has also been well established through sport marketing. Consumers are defined as persons or a group who exchange indirect (payment on TV) or direct payment (such as payment at stadiums) in using a sport or sport product or service (Blann \& Armstrong, 2007). Based on what sport type the customers use, they have been categorized by sport marketing into four classifications: (1) spectators, fans, and sport supporters, (2) sport participants and volunteers, (3) sport services consumers, and (4) sporting goods consumers. In order to understand customers' behaviors, market segmentation is the process of categorizing groups of consumers together, based on their similar needs or wants (A. C. T. Smith \& Stewart, 2007). The strategy of segmenting market involves dividing a specific consumer group into a smaller scale in typical features such as gender, age, needs, or wants, etc. One segment is geography that divides market into different groups according to international, national, or local (suburb or state/country/ province) regions. 
This study examines whether geographic segment is useful to examine sport tourists' behavioral choices of sport attributes for attending a sepak takraw event in Malaysia. Domestic and foreign sport tourists were identified as those who traveled from Malaysia or foreign countries and resided in Kota Kinabalu for at least 24 hours to view a sepak takraw event as the primary purpose of their visit in accordance with Robinson and Gammon's (2004) sport tourism definition.

\section{Nuclei or Sport Event Attributes}

As noted above, the nucleus of the tourist attraction system refers to any attribute or feature of a site that tourists actually visit for their touristic experiences (Leiper, 1990). Applying Leiper's model, sport events can be considered as primary attractions, as sport events directly influence tourists' decisions to travel. In the sport marketing field, sport attributes are considered as products that include either services or sport products, and nonsport products marketed in association with the sport (Blann \& Armstrong, 2007; A. Smith, 2012). The sport consumers do not buy only products or services, but they buy the expectations of benefits that they anticipate will satisfy their needs (Crompton \& McKay, 1997). Therefore, effective sport marketing procedures require understanding customers' wants and needs aligning with sport; then disposing, designing, producing, and delivering to satisfy their needs. In order to understand sport tourists' preferences, previous studies have identified a number of the sport attributes affecting spectators' decisions to travel. A review can be categorized into the following four categories: demographic variables, economic variables, residual variables, and game attractiveness variables (Schofield, 1983). Demographic variables were identified to influence sport tourists' attendance, which include population size and ethnic mix (Branvoid, Pan, \& Gaber, 1997). Economic variables include factors such as substitutes or complements (Zhang, Smith, Pease, \& Jambor, 1997), price (Bernthal \& Graham, 2003; Ferreira \& Armstrong, 2004; Zhang et al., 2005), and income (Hansen \& Gauthier, 1989). Residual variables are preferences that have not otherwise been accounted for, such as the time of the week or season that the event/game is played, the stadium quality (Ferreira \& Armstrong, 2004; Greenwell, Fink, \& Pastore, 2002; Hansen \& Gauthier, 1989), travel distance (Becker \& Suls, 1983; Carmichael, Millington, \& Simmons, 1999; Marcum \& Greenstein, 1985), and the number of years that a team is based in a city (Carmichael et al., 1999; Hansen \& Gauthier, 1989). The majority of previous studies have addressed variables related to the attractiveness of the games or teams and attributes such as promotions and special occasions like bat days (Byon, Zhang, \& Connaughton, 2010; Ferreira \& Armstrong, 2004; Marcum \& Greenstein, 1985; McDonald \& Rascher, 2000), home and visiting team records, players' characteristics (Baade \& Tiehen, 1990; Zhang et al., 2005), and close to competition in a special event (Baade \& Tiehen, 1990; Hansen \& Gauthier, 1989).

In order to more precisely understand the consumers' needs and wants, profiling attendees can guide managerial decision making and marketing (Kotler, Bowen, \& Makens, 2010; Lee, Lee, \& Wicks, 2004). Market segmentation is a marketing and management strategy that profiles tourists and views them as smaller markets with similar consumer needs, characteristics, or behaviors (Kotler, 1980). A review of literature shows that a considerable number of researches have investigated tourists' behaviors based on the origin or place of residence (geographic segmentation) in festivals (e.g., Park, Reisinger, \& Kang, 2008; Shani, Rivera, \& Hara, 2009; Shanka \& Taylor, 2004). However, only a few have studied differences in sport tourists' preferences at sport events (e.g., Qi, Gibson, \& Zhang, 2009; Taks, Chalip, Green, Kesenne, \& Martyn, 2009). For instance, the sport event attributes related to attendance among different types of sport tourists at the Champions Youth Cup (CYC) soccer tournament were investigated by Yusof et al. (2010). They found such important variables as athleticism and team quality from the perception of sport tourists, local spectators, and other tourists. The results from ANOVA analysis also indicated that the three groups did not differ in the eight sport event attributes. The study by Popa et al. (2017) found that degree of physical contact was the most important factor for sport tourists' attendance at Muay Thai traditional sport event and all the sport attributes dimensions 
significantly affected domestic and foreign sport tourists' behavioral intention.

This study investigates the differences in attribute ratings between domestic and foreign sport tourists for attending ISTAF Super Series using Ferreira and Armstrong's (2004) sport attributes scale. Ferreira and Armstrong (2004) studied college students' preferences and behavior-related decisions at university's men's and women's hockey and basketball games. They proposed eight dimensions that involved the attractiveness of the game, entertainment, sport facilities, physical contact, popularity of the sport, promotions and free offerings, accessibility and convenience, and cost. Previous studies that investigated sport tourists' preferences and difference based on geographic segment have used this scale and found it to be reliable (e.g., Popa et al., 2017; Yusof et al., 2010, 2012).

The first dimension-popularity of sport-refers to such variables as crowd density, crowd noise, popularity of game, amount of advertising, popularity of players, rivalry, the opportunity of watching on TV, and game pace. Attractiveness of game as the second proposed dimension refers to team performance and quality, constituting the quality of the opposing team, the quality of the home team, strategy of sport, the reputation of opposing team, the reputation of team, athleticism displayed, and high level of skill displayed. The free offerings and promotions dimension is defined as the sport tourists' concerns about economic issues related sport event products including free offering t-shirts, offering of prizes, free offering of tickets, charitable promotions, and promotion of concessions. The fourth dimension is entertainment, which is defined as an event, performance, or activity designed to entertain sport viewers before or during sporting events. It considers variables such as tailgating, band, cheerleaders, music, and pregame entertainment activities.

The degree of physical contact is the fifth consideration and is related to bodily activities, which include degree of physical contact, degree of violence, amount of speed displayed, and amount of action on the pitch. The sixth dimension is accessibility and convenience, which is defined as the ability to reach the sport event and the quality of the stadium (whether it is easy to access and suitable for sport tourists). It includes such items as seating arrangements, seats location, location convenience, parking accessibility, duration of event, and convenience of schedule. The consideration of sport facility is defined as the quality of stadium infrastructures, which includes the niceness and newness of the sport facilities. Finally, cost as the last dimension refers to the value and price of the sport event tickets and ticket packages.

\section{Method}

The survey instrument used in the data collection was a questionnaire in order to measure demographic profiles and sport attributes related to attending sepak takraw event of ISTAF Super Series.

\section{Data Collection Procedure}

The event used in this study was the ISTAF Super Series, held between October 31 and November 3, 2013, at Likas Complex Stadium in Kota Kinabalu, Sabah, Malaysia and organized by the ISTAF. The tournament included 12 men's and 5 women's national teams from different countries including Indonesia, Brunei, Vietnam, Iran, India, US, Malaysia, Thailand, Germany, Switzerland, Singapore, and the Philippines. On-site self-administered questionnaires were distributed to respondents by a team of four graduate students who were responsible for distributing questionnaires, answering the respondents' questions and collecting completed questionnaires. In order to distinguish sport tourists from spectators, respondents (being over 18 years old) were asked "are you going back to your home town tonight?" and "Is the event the primary purpose of your trip to attend the event?” If respondents replied "yes" to both questions, then they were requested to complete the questionnaires, and these were collected by the graduate students. At the venue, the data collection was done over 4 days during the following time periods: pregame or $1 \mathrm{hr}$ before the kick-off at 9 am when sport tourists had taken their seats, during the half-time break, and during the team change period. All respondents who completed the questionnaires received small souvenirs as a thank you for their time. 


\section{Instrument}

The questionnaire contained 50 items in both Malay and English. Both versions were translated and evaluated by five experts in English and Malay language, who were also familiar with sport management concepts. Initially, the pilot study was conducted as the scale development process with similar stages to enhance the reliability of the generated items before the actual data collection. The pilot was done at a Five Nations Event at Taman Keramat Stadium in Kuala Lumpur, Malaysia during the period between July 24 and 29, 2013, hosted by the Malaysian Sepaktakraw Association (PSM). The domestic and foreign sport tourists who were away from their homelands for at least $24 \mathrm{hr}$ to attend the event were chosen as the population of the pilot study. According to literature, 100 sport tourists in two groups of domestic and foreign sport tourists, who viewed the sepak takraw event as their main purpose of traveling, were selected through a nonprobability sampling as the subjects of the pilot study. However, a total of 78 pilot subjects including 50 domestic sport tourists and 22 foreign sport tourists were included in the pilot study in accordance with Robinson and Gammon's (2004) sport tourist's definition. The domestic sport tourists from Kuala Lumpur who were planning to return to their homeland for the night were excluded in the pilot study. After data analysis and running principle factor component, a set of 50 items remained for inclusion in the final scale.

The first 8 items assess whether or not respondents are sport tourists: "Are you going back to your home town tonight?" $(1=$ yes, $2=$ no); "Is the event the primary purpose of your trip to attend the event?" [1 = yes, 2 = no, "if no, what are the reasons for your trip?” (1: Visiting family/friends, 2: Shopping, 3: Business, 4: Sightseeing, 5: Relaxing in warm place, 6: Meeting local people, 7: Others (please specific)], based on Nogawa et al. (1996), along with a number of demographic profiles (e.g., gender, age, ethnic, marital status, residency, monthly income, and education), based on Yusof et al. (2010). In addition, respondents were asked to rate their important choice of attending the event with 42 items related to event attributes, including popularity of sport (e.g., crowd density, crowd noise, popularity of game, amount of advertising, popularity of players, rivalry, the opportunity of watch on TV, and game pace); attractiveness of game (e.g., quality of opposing team, players' physical attractiveness, quality of player and teams you support, strategy of kicking, strategy of jumping, the reputation of opposing team, the reputation of team, athleticism displayed, and high level of skill displayed); promotion and free offerings (e.g., free t-shirt offering, offering of prizes, free offering of tickets, concessions, charitable promotions, and promotion of concessions); entertainment (e.g., tailgating, band, cheerleaders, music, and pregame entertainment activities); physical contact (e.g., degree of physical contact, degree of violence, amount of speed displayed, and amount of action); accessibility and convenience (e.g., seating arrangements, seats location, location convenience, parking accessibility, duration of event, and schedule convenience); sport facility (e.g., facility newness, and facility niceness); and cost (e.g., ticket cost and ticket package) on a 7-point Likert scale ranging from not important at all (1) to extremely important (7), modified from Ferreira and Armstrong (2004).

\section{Event Site}

The event site selected was Likas Complex Stadium in Kota Kinabalu, Sabah. Kota Kinabalu is the capital city of the state of Sabah, and is located on the tropical island of Borneo, the second most visited tourist destination in Malaysia after Kuala Lumpur. Likas Complex Stadium has been considered as the main sport venue for the region.

\section{Participants}

The population for this research was 1,500 spectators based on the stadium capacity. A nonprobability sampling method was used to select 400 sport tourists during ISTAF Super Series according to Krejcie and Morgan's (1970) sample size. According to the screening questions, the exclusion of 84 nonsport tourists was done. The total of 316 sport tourists were categorized in two groups as domestic sport tourists $(n=224)$ and foreign sport tourists $(n=92)$. The sample includes $80.38 \%$ male sport tourists $(n=254)$ and $19.62 \%$ female sport 
tourists $(n=62)$. Domestic sport tourists were identified as travelers or residents from Malaysia and foreign sport tourists were classified as travelers or residents from countries outside of Malaysia and resident in Kota Kinabalu for at least $24 \mathrm{hr}$ to view the ISTAF Super Series as their primary purpose of visit.

\section{Data Analysis}

Sport tourists' demographic characteristics were analyzed using descriptive statistics including frequencies and percentages. Means and standard deviations were calculated for age and income in addition to an independent samples $t$ test to determine if there was any difference between the two categories regarding these variables. The importance of each event attribute and significant differences in the factors from the view of domestic and foreign sport tourists were identified through the use of means, standard deviations, an independent samples $t$ test and the effect size. The principle component factor analysis using Varimax method was also done on the importance of 42 items of sport attributes from the perception of sport tourists. The data were analyzed using the statistical package for Social Sciences (SPSS) version 21.

\section{Data Preparation and Exploratory Factor Analysis}

Table 1 shows that the values of kurtosis and skewness for the event attributes scale met the critical values required $(+1.96,-1.96)$, indicating that the data did not deviate from normal distribution (Hair, Tatham, Anderson, \& Black, 2009). The function of removing outliers or influential data points

Table 1

Skewness and Kurtosis for Sport Event Attributes

\begin{tabular}{lrr}
\hline Event Attributes Dimension & Skewness & Kurtosis \\
\hline Popularity of sport & -0.753 & 0.697 \\
Attractiveness of game & -0.953 & 0.719 \\
Promotions and free offering & -0.546 & 0.409 \\
Pregame and in-game entertainment & -0.317 & 0.409 \\
Level of physical contact & -1.064 & 1.203 \\
Accessibility and convenience & -0.732 & -0.136 \\
Sport facility & -1.008 & 0.830 \\
Cost & -0.513 & -0.446 \\
\hline
\end{tabular}

was checked in different procedures of the boxplot and normal probability plot (normal Q-Q plot) and nine outliers were altered as extreme values from data. The computed value of zero was obtained for Bartlett's test of sphericity $(<0.05)$, and the value of 0.89 obtained for Kaiser-MeyerOlkin (KMO) (>0.6), indicating that factorability of data was appropriate. The principal component method with Varimax rotation was performed on the importance rating of 42 sport event attributes on the sample of 316 sport tourists [pairwise exclude the cases (persons) if they are missing the data required for the specific analysis].

Eight factors were extracted that explained $67.855 \%$ of the total variance with Eigenvalues greater than 1 (Kaiser, 1960) (Table 2). Henson and Roberts (2006) suggested that at least two or three variables loading on a factor can be meaningful. Based on the criteria of a factor loading equal to or greater than 0.5 (Tabachnick \& Fidell, 2007), a total of 30 variables were loaded on to eight factors. However, 12 variables were eliminated: the amount of physical contact, the amount of violence, quality of player and teams you support, crowd density, crowd noise, amount of advertisement, presence of rivalry, concessions, athleticism displayed, tailgating, players' physical attractiveness, and the duration of event. The last three items were deleted similar to the original scale by Ferreira and Armstrong (2004).

The reliability analysis of the sport event attributes scale was measured by a Cronbach alpha coefficient of more than 0.70 (Pallant, 2010). This scale was found to have high internal consistency with a Cronbach alpha coefficient value of 0.927. The factors were labeled as popularity of sport ( 4 items, $\alpha=0.694$ ), attractiveness of game (6 items, $\alpha=0.828$ ), promotion and free offering (5 items, $\alpha=0.773$ ), entertainment (4 items, $\alpha=0.722$ ), physical contact ( 2 items, $\alpha=0.753$ ), accessibility and convenience ( 5 items, $\alpha=0.891$ ), sport facility ( 2 items, $\alpha=0.879$ ), and cost ( 2 items, $\alpha=0.899$ ).

\section{Findings}

\section{Sport Tourists' Demographic Profiles}

The results of this research report on a sample of 316 subjects as certain sport tourists at sepak 
Table 2

Rotated Component Matrix for Sport Event Attributes: Principal Component With Varimax Rotation

\begin{tabular}{ll}
\hline Factors & Loadings \\
\hline Factor 1: Accessibility and convenience & \\
Opportunity to watch sepak takraw on TV & 0.504 \\
The pace of the game & 0.521 \\
Parking accessibility & 0.611 \\
Location convenience & 0.761 \\
Seating arrangements for spectators & 0.863 \\
Seats location (sightlines) & 0.809 \\
Schedule convenience & 0.632 \\
Factor 2: Physical contact & \\
The amount of speed displayed & 0.746 \\
The amount of action in sepak takraw & 0.696 \\
The kicking strategy in sepak takraw & 0.841 \\
The jumping strategy in sepak takraw & 0.807 \\
The high level of skill displayed (by player) & 0.792 \\
Factor 3: Promotions and free offering & \\
Offering free t-shirts & 0.610 \\
Offering free tickets & 0.785 \\
Charitable or socially responsible promotion & 0.605 \\
Promotions on concessions (food and beverage) & 0.627 \\
Factor 4: Attractiveness of game & \\
Quality of opposing teams and players & 0.724 \\
The reputation of team and player that you support (cheer up) & 0.709 \\
The reputation of opposing teams and players & 0.757 \\
Pregame activity at the event & 0.564 \\
Factor 5: Entertainment & \\
Cheerleaders & 0.697 \\
Band & 0.902 \\
Music & 0.858 \\
Factor 6: Sport facility & 0.802 \\
Niceness of facility & 0.618 \\
Factor 7: Popularity of sport & 0.619 \\
The popularity of sepak takraw & \\
Player's and team's popularity & 0.684 \\
Factor 8: Cost & \\
Price of tickets & \\
Ticket package options & \\
\hline & \\
\hline
\end{tabular}

takraw tournament of ISTAF Super Series. Table 3 shows the demographic profile of sport tourists, with 224 (71.89\%) domestic sport tourists and 92 (29.11\%) respondents categorized as foreign sport tourists whose primary purpose of attendance was to watch the event. As was expected, the events attracted a greater number of Malaysian sport tourists $(70.89 \%)$ compared with foreigners $(29.11 \%)$ from 11 countries including Indonesia, Brunei, Vietnam, Iran, India, US, Thailand, Germany, Switzerland, Singapore, and the Philippines. The gender profile shows that the sample was primarily comprised of male sport tourists; there were $82.1 \%$ male respondents in the domestic group and $76.1 \%$ in the foreign group, which greatly outnumbered the females of domestic sport tourists (17.9\%) and those of foreign sport tourists (23.9\%).

The majority of domestic sport tourists were married (59.8\%), whereas those from foreign countries were equally likely to be single $(49.9 \%)$ or married (48.9\%). The data also show that the age of the two groups significantly resembled each other ( $p=0.387$ ); the domestics had average age of 34.4 years, with all respondents falling between the 
Table 3

Domestic and Foreign Sport Tourists’ Demographic Profiles

\begin{tabular}{|c|c|c|}
\hline Variables & $\begin{array}{l}\text { Domestic Sport Tourists } \\
\text { [Frequency (\%)] }\end{array}$ & $\begin{array}{l}\text { Foreign Sport Tourists } \\
\text { [Frequency (\%)] }\end{array}$ \\
\hline Numbers & $224(70.89)$ & $92(29.11)$ \\
\hline \multicolumn{3}{|l|}{ Gender } \\
\hline Male & $184(82.1)$ & $70(76.1)$ \\
\hline Female & $40(17.9)$ & $22(23.9)$ \\
\hline \multicolumn{3}{|l|}{ Marital status } \\
\hline Single & 89 (39.73) & 45 (48.9) \\
\hline Married & $134(59.82)$ & $44(47.8)$ \\
\hline Other & $1(0.45)$ & $3(3.3)$ \\
\hline \multicolumn{3}{|l|}{ Age } \\
\hline Mean & 34.48 & 33.29 \\
\hline Min-Max & $19-59$ & $19-58$ \\
\hline$S D$ & 10.64 & 10.66 \\
\hline \multicolumn{3}{|l|}{ Ethnicity } \\
\hline Malay & $93(41.5)$ & $8(8.7)$ \\
\hline White/Caucasian & & $17(18.5)$ \\
\hline Asian (Murat, Sungai, Dusu, Bugis, Suluk) & $125(55.8)$ & $55(59.8)$ \\
\hline China & $4(1.8)$ & \\
\hline Indian & $2(0.9)$ & $12(13)$ \\
\hline \multicolumn{3}{|l|}{ Country residency } \\
\hline \multicolumn{3}{|l|}{ Foreign countries } \\
\hline Singapore & & $12(13)$ \\
\hline Brunei & & $7(7.6)$ \\
\hline Iran & & $12(13)$ \\
\hline Thailand & & $5(5.4)$ \\
\hline Switzerland & & $3(3.3)$ \\
\hline Indonesia & & $21(22.8)$ \\
\hline India & & $12(13)$ \\
\hline United States & & $6(6.5)$ \\
\hline Philippines & & $3(3.3)$ \\
\hline Vietnam & & $5(5.4)$ \\
\hline Germany & & $6(6.5)$ \\
\hline \multicolumn{3}{|l|}{ Malaysia } \\
\hline Kuala Lumpur & $9(4)$ & \\
\hline Selangor & $3(1.3)$ & \\
\hline Pualu Pinang & $4(1.8)$ & \\
\hline Sabah & $178(79.5)$ & \\
\hline Sarawak & $11(4.9)$ & \\
\hline Wilayah Persekutuan & 3 (1.3) & \\
\hline Johor & $8(3.6)$ & \\
\hline Perak & $4(1.8)$ & \\
\hline Kedah & $1(0.4)$ & \\
\hline Pahang & $3(1.3)$ & \\
\hline \multicolumn{3}{|l|}{ Education } \\
\hline Below bachelor’s degree & $157(70.1)$ & $41(44.6)$ \\
\hline Bachelor's degree & $47(21)$ & $27(29.3)$ \\
\hline Master's degree & $18(8)$ & $22(23.9)$ \\
\hline Doctorate degree & $2(0.9)$ & $2(2.2)$ \\
\hline \multicolumn{3}{|l|}{ Employment status } \\
\hline Full time & $127(56.7)$ & $40(44.6)$ \\
\hline Student & $38(17)$ & $29(31.5)$ \\
\hline \multicolumn{3}{|l|}{ Monthly income } \\
\hline Part time & $14(6.3)$ & $1(1.1)$ \\
\hline Unemployed & $3(1.3)$ & $4(4.3)$ \\
\hline Own business & 29 (12.9) & $13(14.1)$ \\
\hline Retired & $4(1.8)$ & $2(2.2)$ \\
\hline Others & $9(4)$ & $3(3.3)$ \\
\hline Mean & 1,762 & $3,533.57$ \\
\hline Min-Max & $0-17,000$ & $0-50,000$ \\
\hline SD & $1,992.21$ & $6,554.879$ \\
\hline
\end{tabular}


Table 4

Demographic Characteristics’ Differences Among Domestic and Foreign Sport Tourists

\begin{tabular}{lrcccc}
\hline Variables & $N$ & Mean $(S D)$ & $t$-Statistics & $d f$ & Sig. Level \\
\hline Age & & & 0.867 & 155.524 & 0.387 \\
$\quad$ Domestic & 224 & $34.48(10.64)$ & & & \\
$\quad$ Foreign & 92 & $33.29(10.66)$ & & & \\
Monthly income & & & & & \\
$\quad$ Domestic & 224 & $1762.05(1992.21)$ & & \\
$\quad$ Foreign & 92 & $3533.55(6554.87)$ & & & \\
$*_{p}^{*}<0.05$. & & & & & \\
& & & & & \\
\end{tabular}

ages of 19 to 59 and foreign sport tourists had an average age of 33.2 years and all were between the ages of 19 to 58 . The gender profile indicates that the sport was much more popular with male participants (domestic $=82.1 \%$, foreign $=76.1 \%$ ) who were more willing to attend to the event, while this suggests that the event was not sufficiently important for female sport tourists (domestic $=17.9 \%$, foreign $=23.9 \%$ ) to encourage them to travel.

Most domestic sport tourists came from the state of Sabah (79.5\%) and reported their ethnic background as Malay (41.5\%) and Asian (55.8\%). However, foreign countries including Indonesia with $22.8 \%$, Singapore, Iran, and India, each with $13 \%$, had the highest numbers of participants and mostly were from Asian (59.8\%) and White or Caucasian ethnicity (18.5\%). With regard to education, a large number of both categories had the educational attainment of below bachelor's degree (domestic $=70 \%$, foreign $=44.6 \%$ ), followed by bachelor's degree holders (domestic $=21.1 \%$, foreign $=29.3 \%$ ). In terms of monthly income, the two groups significantly differed ( $p=0.013$ ) (Table 4) that an average monthly earning of RM 1759.91 for the domestics was about two times lower than the average monthly income of RM 3533.57 for the foreigners. This suggests that it is much more expensive to travel from oversees to attend the event, so it could be expected that these sport tourists were wealthier. However, this supports sepak takraw event that attracts wealthier international sport tourists.

\section{Description of Sport Event Attributes}

The eight dimensions of sport event attributes were classified based on their importance for domestic sport tourists' attendance with mean values ranging from 5.99 to 4.56 and are presented in Table 5. The results show that five dimensions were above the total mean $(M=5.46)$, and three categories were lower than 5.46. The categories of attractiveness of game $(M=5.99, S D=0.87)$, sport facility $(M=5.906, S D=1.12)$, accessibility and convenience ( $M=5.85, S D=1.00)$, and degree of physical contact $(M=5.84, S D=1.10)$ were rated high. However, factors related to entertainment $(M=4.74, S D=1.02)$ and cost aspects $(M=4.56$, $S D=1.83$ ) were found as unimportant influences on attendance.

Table 6 provides data on the main dimensions responsible for foreign sport tourists' attendance with mean scores ranging from 6.02 to 4.82 . Four dimensions had the mean scores above the total mean of 5.40; however, the majority of foreign sport tourists seemed more eager to score the dimension of physical contact $(M=6.00, S D=0.94)$ and game attractiveness $(M=5.77, S D=0.85)$ high, while the factor of entertainment $(M=4.82, S D=1.38)$ was rated low.

\section{Table 5}

The Importance of Sport Event Attribute Dimension for Domestic Sport Tourists

\begin{tabular}{ll}
\hline Dimension & Mean (SD) \\
\hline Attractiveness of game & $5.99(0.87)$ \\
Sport facility & $5.90(1.12)$ \\
Accessibility and convenience & $5.85(1.00)$ \\
Level of physical contact & $5.84(1.10)$ \\
Popularity of sport & $5.63(0.98)$ \\
Promotions and free offerings & $5.15(1.07)$ \\
In-game and pregame entertainment & $4.72(1.02)$ \\
Cost & $4.56(1.83)$ \\
Total mean & 5.46 \\
\hline
\end{tabular}


Table 6

The Importance of Sport Event Attributes Dimensions for Foreign Sport Tourists

\begin{tabular}{ll}
\hline Variables & Mean $(S D)$ \\
\hline Level of physical contact & $6.01(0.94)$ \\
Attractiveness of game & $5.77(0.85)$ \\
Accessibility and convenience & $5.51(1.10)$ \\
Popularity of sport & $5.47(0.91)$ \\
Sport facility & $5.39(1.31)$ \\
Promotions and free offering & $5.24(1.13)$ \\
Cost & $5.01(1.42)$ \\
Entertainment & $4.82(1.38)$ \\
Total mean & 5.41 \\
\hline
\end{tabular}

\section{t Test of Sport Event Attributes}

The differences in sport attributes between domestic and foreign sport tourists were done by using $t$ test analysis and the effect size proposed by Cohen (1988) (smaller effect $=0.01$, moderate effect $=0.06$, large effect $=0.14$ ). Independent $t$ test results in Table 7 show that there were significant differences between domestic and foreign sport tourists in four dimensional categories of event attributes $(p<0.05)$. Three sport event attributes such as accessibility and convenience, attractiveness of game, and sport facility were significantly important for domestic sport tourists' attendance while only cost factor was perceived by foreign sport tourists.

The first significant difference was shown in the attribute of accessibility and convenience $\left(p=0.012, \eta^{2}=0.019\right)$. The findings further show the mean scores of accessibility and convenience attribute perceived by domestic tourists $(M=5.85)$, which was significantly higher than that of foreign group $(M=5.51)$. The second significant difference was found on game attractiveness attribute $\left(p=0.042, \eta^{2}=0.013\right)$. The attribute was rated higher by the domestics $(M=5.99)$ when compared with the foreigners $(M=5.77)$. There was also a statistically significant difference between the two groups regarding sport facility factor ( $p=0.001$, $\eta^{2}=0.032$ ). According to the mean scores, the domestic group $(M=5.90)$ perceived this factor stronger than the foreigners $(M=5.39)$. The attribute of cost was only reported as a significant

Table 7

Differences in Sport Event Attribute Dimensions Between Domestic and Foreign Sport Tourists

\begin{tabular}{|c|c|c|c|c|c|c|}
\hline Factors & $N$ & Mean $(S D)$ & $t$-Statistics & $d f$ & Sig. Level & $\eta^{2}$ \\
\hline 1. Accessibility and convenience & & & 2.530 & 155.763 & $0.012 *$ & 0.019 \\
\hline Domestic & 224 & $5.85(1.00)$ & & & & \\
\hline Foreign & 92 & $5.51(1.10)$ & & & & \\
\hline 2. Physical contact & & & -1.379 & 196.639 & 0.169 & 0.006 \\
\hline Domestic & 224 & $5.84(1.10)$ & & & & \\
\hline Foreign & 92 & $6.01(0.94)$ & & & & \\
\hline 3. Attractiveness of game & & & 2.052 & 172.769 & $0.042 *$ & 0.013 \\
\hline Domestic & 224 & $5.99(0.872)$ & & & & \\
\hline Foreign & 92 & $5.77(0.85)$ & & & & \\
\hline 4. Entertainment & & & -0.611 & 133.517 & 0.542 & 0.001 \\
\hline Domestic & 224 & $4.72(1.02)$ & & & & \\
\hline Foreign & 92 & $4.82(1.38)$ & & & & \\
\hline 5. Sport facility & & & 3.262 & 148.038 & $0.001^{*}$ & 0.032 \\
\hline Domestic & 224 & $5.90(1.12)$ & & & & \\
\hline Foreign & 92 & $5.39(1.31)$ & & & & \\
\hline 6. Popularity of sport & & & 1.368 & 181.627 & 0.173 & 0.005 \\
\hline Domestic & 224 & $5.63(0.98)$ & & & & \\
\hline Foreign & 92 & $5.39(0.31)$ & & & & \\
\hline 7. Promotion and free offering & & & -1.319 & 173.051 & 0.189 & 0.005 \\
\hline Domestic & 224 & $5.15(0.75)$ & & & & \\
\hline Foreign & 92 & $5.24(1.13)$ & & & & \\
\hline 8. Cost & & & -2.367 & 217.130 & $0.019 *$ & 0.017 \\
\hline Domestic & 224 & $4.56(1.83)$ & & & & \\
\hline Foreign & 92 & $5.01(1.42)$ & & & & \\
\hline
\end{tabular}

$* p<0.05$. 
motivator of foreign sports attendance $(p=0.019$, $\left.\eta^{2}=0.017\right)$ who had higher scores $(M=5.01)$ than the domestics $(M=4.56)$.

\section{Discussion}

This study uses the human and nucleus elements of the tourist attraction system (Leiper, 1990) to examine the sport event attributes attract domestic and foreign sport tourists to the sepak takraw event. In the tourist attraction system, tourists' behaviors are focused on searching for satisfaction at leisure outside their home environment. These leisure tourists are also in search of desirable attractions of the attraction system for their experience. In this study the human element of Leiper's model is defined as sport tourists' behaviors and demographic characteristics. According to his model, sport tourists can take a trip if they have individuals' nonmental and mental attributes, needs, and abilities. Segmenting sport tourists based on geographic market is an effective marketing strategy in order to target sport tourists with similar needs, wants, and characteristics in the same regions (e.g., Blann \& Armstrong, 2007; A. C. T. Smith \& Stewart, 2007). Understanding sport tourists' preferred sport attributes help sport tourism marketers to provide sport services which satisfy sport tourists needs (Popa et al., 2017; Yusof et al., 2010).

The assessment of sport tourists' profiles provides a valuable database for developing and implementing marketing plans to draw sport tourists and effectively develop the process including different tour packaging, promoting, and delivering sport to them. Within tourism contexts, the potential for small-scale sport events to include more sport tourists' activities is doubtful (Gibson, Willming, \& Holdnak, 2003; Higham \& Hinch, 2003). The results from the ISTAF Super Series as small-scale sport events in Malaysia significantly attracted a large number of domestic sport tourists (71.89\%). With regard to the smaller group of international sport tourists, about $40 \%$ of foreign sport tourists came from nearby South-Asian countries such as Thailand, the Philippines, Indonesia, and Brunei as originators of sepak takraw. This supports Higham's (1999) study that small-scale sport events attract a large cohort of the host community as opposed to mega-sport events, which attract more international tourists. However, there is a challenge for sport authorities to attract tourists from foreign countries through staging small-scale sport events.

Regarding the nucleus component of the tourist attraction system, sport tourists are in search of appropriate nucleus attractions or individual experiences (Leiper, 1990). The nucleus as the central attraction of the system provides any attribute or feature that tourists actually visit for their touristic experiences. Sports events themselves can be centered as nucleus attractions for sport tourists' experiences. In small-scale tourism, it is important for tourism authorities to understand sport attributes that affect sport tourists to decide on attending such events (e.g., Gibson et al., 2003; Higham \& Hinch, 2003) that are different between different market segmentation (Dolinting et al., 2013; Popa et al., 2017; Yusof et al., 2010). The results of previous studies in sport marketing revealed that sport attributes were important for understanding the consumption behavior of the sport tourists (e.g., Ferreira \& Armstrong, 2004; Hansen \& Gauthier, 1989; Popa et al., 2017; Yusof et al., 2012; Zhang et al., 2005).

Sepak takraw as a sport event can be as a primary motive for attending for sport tourists. At the ISTAF Super Series, the sport event's unique combination of characteristics provided a variety of attractions that influenced sport tourists' attendance. Within the descriptive findings of this study, most domestic sport tourists identified that the categories of attractiveness of game $(M=5.99, S D=0.87)$ and sport facility $(M=5.90, S D=1.12)$ were important factors leading to their attendance, while physical contact dimension $(M=6.02, S D=0.95)$ and game attractiveness $(M=5.77, S D=0.85)$ were ranked as important factors by foreign sport tourists. The results confirmed previous studies in small-scale sport tourism and marketing literature. Game attractiveness has been identified as the most important attribute in previous studies of small-scale sport events across a wide range of sports, including AFL, MLB, NBA, NFL, NHL, hockey, baseball, and soccer (Bernthal \& Graham, 2003; Byon et al., 2010; Zhang et al., 2005). Another important factor was sport facility, which has previously been reported (Greenwell et al., 2002; King, 1999). It is also interesting to note that physical contact was mostly perceived by sport tourists at Muay 
Thai traditional sport event (Popa et al., 2017) and by the spectators of various events of men's and women's basketball and hockey (Ferreira \& Armstrong, 2004).

The $t$ test analysis showed significant differences in the sport attributes of sport facility, attractiveness of game, convenience and accessibility, and cost between domestic and foreign sport tourists. These support the studies on small-scale sport events such as Bernthal and Graham (2003) who found that the play of game itself and value for money are significant attendance factors among college baseball and minor baseball fans. Moreover, with exception of sport facility, the findings also reflect those of Hansen and Gauthier, who identified that scheduling of games, the quality of teams, players attaining team or league records, ticket price, the forms of entertainment, and seating, cleanliness, and accessibility were as significant factors affected spectators attending of baseball, the NFL, and the MISL.

The importance of cost attribute was found for foreign sport tourists, which shows that they had to spend on their trips, although sepak takraw event ticket cost were assigned free for all of them. This recommends International Sepak Takraw Asian Federation (ISTAF) and Malaysia Sepaktakraw Association (PSM) to provide the opportunity of saving cost for attending ISTAF Super Series in Kota Kinabalu, Malaysia including discounted flight tickets and packages. The most important event attributes that were perceived by domestic sport tourists for attending the event were game attractiveness, sport facility, and convenience and accessibility. Domestic sport tourists considered some attractiveness of the game (the rules, players' athleticism, etc.) for their attendance. Because most of them were from Malaysia, which is the home of sepak takraw, they know more about the game and its attractions. The findings confirm that domestic sport tourists perceived sport facility (e.g., the quality of infrastructures or equipment, facilitating the performance of the sport and courts) as the most important attribute and they considered (e.g., accessible venues, accessible parking bays, the convenience of timetable, and convenient location). This is likely because most domestic tourists were local from Sabah and would be familiar with Likas Stadium and use their own transport to and from the event.

\section{Conclusion, Implications, and Recommendations}

This article has explored the human and nucleus components of Leiper's (1990) tourist attraction system among domestic and foreign sport tourists across the ISTAF Super Series in Kota Kinabalu, Malaysia. According to $t$ test analysis, the findings reveal that sport attributes appeared to capture significant difference between foreign and domestic sport tourists' choices of experiences over four attribute dimensions of game attractiveness, convenience and accessibility, cost, and sport facility.

The findings of this study have a number of practical implications for those involved in attraction management and sport marketing such as the International Sepak Takraw Asian Federation (ISTAF) and PSM. The change in the demographics of sport consumers leads to greater diversity and sport marketers need to respond this diversity in their attempts to develop successful marketing plans. The research findings offer opportunities for marketing campaigns to more directly target certain segments in Indonesia, Singapore, Iran, and India as well as Malaysia. Within the results, the great support of Malaysians for attending ISTAF Super Series was important but sport marketers need to target more foreign countries in order to maximize the economic benefits through positioning sepak takraw events in the future. The low attendance of foreign sport tourists suggests that more needs to be done to attract international high-income sport tourists staying more than 1 night in the destination. As such, there is a need for ISTAF and PSM in cooperation with Malaysia tourism to promote the event and possibly reduce costs by providing packages overnight visitors.

The findings showed that the event attracted predominantly male sport tourists across the 19 to 58-59-year age groups with educational attainment below bachelor's or at bachelor's degree level, who have full time jobs or are students. This suggests that ISTAF and PSM should target organizations such as universities, schools, and government offices in Malaysia. In order to encourage more visitors from these market segments, the sport marketers need to work with hotels and state organizations to have meetings and conferences or other events when sepak takraw event is held in Kota Kinabalu. 
Sport attributes as tourist attractions that appeal to different geographic markets need to be identified and promoted. The results show that marketing strategies should pay attention to provide promotion packages such as lower cost tickets to foreign sport tourists, while providing more accessibility and convenience, and emphasizing the sport facilities and the attractiveness of game to domestic sport tourists. Sport organizers need to offer different promotions in ticket and tour packages in order to decrease the total costs of the event for foreign sport tourists more than the domestic market. For domestic sport tourists, teams are recommended to consider technical changes to the rules and regulations that would increase the teams' strategies to speed up the game. Moreover, marketing strategies should take into account the design of the existing infrastructures of stadiums and provisions of facilities including sports courts, sport equipment, and materials. Besides, providing complimentary parking and accessible spaces for vehicles as well as purchasing parking passes in advance online should be noted for more effective plans. Another effective function of facility operators in stadiums is related to the provision of the type of seating available to spectators, the number of expected attendees, and the length of the event and the timing of the event.

Any study has its limitations. In this study, there was the risk that the different skills of the research assistants who administered the questionnaire instrument, such as explaining question items to the respondents, may lead to inconsistencies in data collection. Therefore, a team of four trained graduate students were placed on site to ensure consistent representation and explanations of the questions to domestic and foreign sport tourists. In surveying an international cohort there was a potential constraint regarding language barriers, which may have limited respondents' ability to understand the question items and subsequently not answered the questions. Thus, questionnaires were designated in both English and Malay language, and a pilot study was conducted to try and address this issue.

A traditional sport event as the nuclei of an attraction system may function as a secondary or tertiary motivation for attending the event. Future studies could examine the level of motivation that sport tourists assign to different scales of sport events. We also call for further research on traditional sport events using qualitative methods to examine limitations around current assumptions and definitions regarding sport tourists' typologies. Moreover, the role of small-scale traditional sport events as a more sustainable form of sports tourism, with the opportunity to celebrate a destination's culture without the drawbacks associated with mega-events warrants further investigation.

\section{References}

Baade, R. A., \& Tiehen, L. J. (1990). An analysis of major league baseball attendance, 1969-1987. Journal of Sport \& Social Issues, 14(1), 14-32.

Becker, M. A., \& Suls, J. (1983). Take me out to the ballgame: The effects of objective, social, and temporal performance information on attendance at major league baseball games. Journal of Sport Psychology, 5(3), 302-313.

Bernthal, M. J., \& Graham, P. J. (2003). The effect of sport setting on fan attendance motivation: The case of minor league vs. collegiate baseball. Journal of Sport Behavior, 26(3), 223-239.

Blann, F. W., \& Armstrong, K. L. (2007). Sport marketing. In J. B. Parks, J. Quaterman, \& L. Thibault (Eds.), Contemporary sport management (pp. 193-217). Champaign, IL: Human Kinetics.

Branvoid, S., Pan, D. W., \& Gaber, T. (1997). Effects of winning percentage and market size on attendance in minor league baseball. Sport Marketing Quarterly, 6, 35-42.

Byon, K. K., Zhang, J. J., \& Connaughton, D. P. (2010). Dimensions of general market demand associated with professional team sports: Development of a scale. Sport Management Review, 13(2), 142-157.

Carmichael, F., Millington, J., \& Simmons, R. (1999). Elasticity of demand for rugby league attendance and the impact of BskyB. Applied Economics Letters, 6(12), 797-800.

Cohen, J. (1988). Statistical power analysis for the behavioral sciences (2nd ed.). Hillsdale, NJ: Lawrence Earlbaum Associates.

Crompton, J. L., \& McKay, S. L. (1997). Motives of visitors attending festival events. Annals of Tourism Research, 24(2), 425-439.

Dolinting, E. E., Yusof, A., \& Soon, C. C. (2013). Understanding sport tourists' motives and perceptions of Sabah, Malaysia as a sport tourist destination. Journal of Physical Education and Sport, 13(4), 547-556.

Ferreira, M., \& Armstrong, K. L. (2004). An exploratory examination of attributes influencing students' decisions to attend college sport events. Sport Marketing Quarterly, 13(4), 194-208.

Fredline, E. (2005). Host and guest relations and sport tourism. Sport in Society, 8(2), 263-279.

Gammon, S., \& Robinson, T. (2003). Sport and tourism: A conceptual framework. Journal of Sport Tourism, 8(1), 21-26. 
Getz, D. (2008). Event tourism: Definition, evolution, and research. Tourism Management, 29(3), 403-428.

Gibson, H. J. (Ed.). (2013). Sport tourism: Sport in the global society. Oxon, UK: Routledge.

Gibson, H. J., Kaplanidou, K., \& Kang, S. J. (2012). Smallscale event sport tourism: A case study in sustainable tourism. Sport Management Review, 15(2), 160-170.

Gibson, H. J., Willming, C., \& Holdnak, A. (2003). Smallscale event sport tourism: Fans as tourists. Tourism Management, 24(2), 181-190.

Greenwell, T. C., Fink, J. S., \& Pastore, D. L. (2002). Assessing the influence of the physical sports facility on customer satisfaction within the context of the service experience. Sport Management Review, 5(2), 129-148.

Hair, J. F., Tatham, R. L., Anderson, R. E., \& Black, W. (2009). Multivariate data analysis (7th ed.). Englewood Cliffs, NJ: Prentice Hall.

Hall, C. M. (1992). Adventure, sport and health tourism. In B. Weiler \& C. M. Hall (Eds.), Special interest tourism (pp. 141-158). London, UK: Bellhaven Press.

Hansen, H., \& Gauthier, R. (1989). Factors affecting attendance at professional sport events. Journal of Sport Management, 3(1), 15-32.

Henson, R. K., \& Roberts, J. K. (2006). Use of exploratory factor analysis in published research common errors and some comment on improved practice. Educational and Psychological Measurement, 66(3), 393-416.

Higham, J. (1999). Commentary-sport as an avenue of tourism development: An analysis of the positive and negative impacts of sport tourism. Current Issues in Tourism, 2(1), 82-90.

Higham, J., \& Hinch, T. D. (2003). Sport, space, and time: Effects of the Otago Highlanders franchise on tourism. Journal of Sport Management, 17(3), 235-257.

Hinch, T. D., \& Higham, J. E. (2011). Sport tourism development (Vol. 13). Briston, UK: Channel View Publications.

Kaiser, H. F. (1960). The application of electronic computers to factor analysis. Educational and Psychological measurement, 20, 141-151.

King, B. (1999). A ballpark boom on the farm. Street \& Smith's Sports Business Journal, 23-32.

Kotler, P. (1980). Principles of marketing. Englewood Cliffs, NJ: Prentice Hall.

Kotler, P., Bowen, J. T., \& Makens, J. C. (2010). Marketing for hospitality and tourism (5th ed.). Upper Saddle River, NJ: Pearson Prentice Hall.

Krejcie, R. V., \& Morgan, D. W. (1970). Determining sample size for research activities. Educational and Psychological Measurement 30(3), 607-610.

Lavega, P. (2006). Traditional sports and games in 21st century Europe: Future Challenges In P. Lavega (Ed.), Traditional games and society in Europe. Eurepean culture in the light of traditional sports and games. Barcelona, Spain: European Association of Traditional Games and Sports (ETSGA).
Lee, C.-K., Lee, Y.-K., \& Wicks, B. E. (2004). Segmentation of festival motivation by nationality and satisfaction. Tourism Management, 25(1), 61-70.

Leiper, N. (1990). Tourist attraction systems. Annals of Tourism Research, 17(3), 367-384.

Marcum, J. P., \& Greenstein, T. (1985). Factors affecting attendance of major league baseball: 11 . A within-season analysis. Sociology of Sport Journal, 2(4), 117-127.

McDonald, M., \& Rascher, D. A. (2000). Does bat day make cents? The effect of promotions on the demand for baseball. Journal of Sport Management, 14(1), 8-27.

Megat, A. K., \& Virdati, M. R. (2012). Sports in South Asia, Southeast Asia and Oceania. In M. Li, E. McIntosh, \& G. Bravo (Eds.), International sport management (pp. 177-198). Champaign, IL: Human Kinetics.

Nauright, J. (1996). A besieged tribe? Nostalgia, white cultural identity and the role of rugby in a changing South Africa. International Review for the Sociology of Sport, 31(1), 69-86.

Nogawa, H., Yamaguchi, Y., \& Hagi, Y. (1996). An empirical research study on Japanese sport tourism in sportfor-all events: Case studies of a single-night event and a multiple-night event. Journal of Travel Research, 35(2), 46-54.

Pallant, J. (2010). SPSS survival manual: A step by step guide to data analysis using SPSS (4th ed.). Maidenhead, UK: McGraw-Hill International.

Park, K.-S., Reisinger, Y., \& Kang, H.-J. (2008). Visitors' motivation for attending the South Beach Wine and Food Festival, Miami Beach, Florida. Journal of Travel \& Tourism Marketing, 25(2), 161-181.

Pillay, U., \& Bass, O. (2008). South Africans believe 2010 can lift them, but how high. HSRC Review, 6(1), 12.

Popa, A., Yusof, A., \& Soh., K. G. (2017). Investigating sport tourists' perceived attributes of Muay Thai, event satisfaction and behavioural intentions of attending future events. International Journal of Academic Research in Business and Social Sciences, 7(6), 457-465.

Qi, C. X., Gibson, H. J., \& Zhang, J. J. (2009). Perceptions of risk and travel intentions: The case of China and the Beijing Olympic Games. Journal of Sport \& Tourism, 14(1), 43-67.

Renson, R. (1992). Save our sports. The UNESCO Courier, 45, 41-45.

Richards, G. (2002). Tourism attraction systems: Exploring cultural behavior. Annals of Tourism Research, 29(4), 1048-1064.

Robinson, T., \& Gammon, S. (2004). A question of primary and secondary motives: Revisiting and applying the sport tourism framework. Journal of Sport \& Tourism, 9(3), 221-233.

Schofield, J. A. (1983). Performance and attendance at professional team sports. Journal of Sport Behaviour, 6(4), 196-206.

Shani, A., Rivera, M. A., \& Hara, T. (2009). Assessing the viability of repeat visitors to cultural events: Evidence 
from the Zora! Festival. Journal of Convention \& Event Tourism, 10(2), 89-104.

Shanka, T., \& Taylor, R. (2004b). A correspondence analysis of sources of information used by festival visitors. Tourism Analysis, 9(1/2), 161-181.

Smith, A. (2012). Introduction to sport marketing. London, UK: Routledge.

Smith, A. C. T., \& Stewart, B. (2007). The travelling fan: Understanding the mechanisms of sport fan consumption in a sport tourism setting. Journal of Sport \& Tourism, 12(3-4), 155-181.

Standeven, J., \& Knop, P. D. (1998). Sport tourism. Champaign, IL: Human Kinetics Publishers.

Tabachnick, B. G., \& Fidell, L. S. (2007). Using multivariate statistics (5th ed., Vol. 3). Boston, MA: Pearson Education.

Taks, M., Chalip, L., Green, B. C., Kesenne, S., \& Martyn, S. (2009). Factors affecting repeat visitation and flow-on tourism as sources of event strategy sustainability. Journal of Sport \& Tourism, 14(2/3), 121-142.

United Nations Educational, Scientific and Cultural Organization. (2005). Preliminary report on the desirability and scope of an international charter on traditional games and sports. Paris, France: Author.

Yusof, A., Shah, P. M., \& Geok, S. K. (2010). Sport events as a tourist attraction: A study of the champions youth cup in Malaysia. International Journal of Sport \& Society 1(1), 70-109.

Yusof, A., Shah, P. M., \& Geok, S. K. (2012). Application of Leiper's tourist attraction system to small-scale sport event tourism in Malaysia. World Applied Sciences Journal, 18(7), 896-900.

Zhang, J. J., Piatt, D. M., Ostroff, D. H., \& Wright, J. W. (2005). Importance of in-game entertainment amenities at professional sporting events: A case for NBA season ticket holders. Journal of Contemporary Athletics, 2(1), $1-24$.

Zhang, J. J., Smith, D. W., Pease, D. G., \& Jambor, E. A. (1997). Negative influence of market competitors on the attendance of professional sport games: The case of a minor league hockey team. Sport Marketing Quarterly, 6(3), 31-40. 